\title{
What's in a Name? The Semantics of Migration and Its Policy Implications
}

\author{
Nguh Nwei Asanga Fon \\ Eastern Mediterranean University, Famagusta, North Cyprus,nguhnwei@gmail.com
}

\begin{abstract}
Across the globe, migration has emerged as one of the most daunting challenges bedeviling globalization. The second decade of the 21 st Century has been marked by issues on how to manage influx of migrants on both sides of the Atlantic (the European Migrant Crisis of 2015 and debates on 'Migrant Caravan' and border security in the US). A major borne of contention on migration is a war of words over its framing. The semantics of migration are meticulously exploited by rival politicians and political parties, policy actors, and other stakeholders to frame the issue, orient policy and mobilize support or acquiescence to their cause (usually securitization versus accommodation). This paper probes into the discourse on migration with a focus on its framing by pro and anti-migration actors and stakeholders and how this has affected policy decisions and actions concerning the issue. Empirical cases of how migration was framed in Europe and the US were examined with a greater tendency towards securitization. Recommendations were also advanced on how to resolved the migration stalemate with the de-politicization of the term as a starting point.
\end{abstract}

KEYWORDS: Migration, Immigration, Migrant crisis, Refugee, 'Open door policy'

\section{Introduction}

From the European migrant crisis which erupted in 2015 with an influx of more than a million refugees and migrants to the shores of Europe; to the Central American migrant caravan to the US through the US/Mexico borders in December 2018; and the debate on border security between the Trump Administration and the US Congress, migration has become an epic challenge to the contemporary international system. Debates over migration and what policy measures are needed to confront the challenge has deeply polarized states; divided politicians and their supporters, and created a wedge in international institutions between pro and anti-migration camps.

A major borne of contention on migration is a war of words over its framing. "What's in a name?" Shakespeare's Juliet famously asked. As far as the debate over migration and its policy implications are concern, a big deal. The semantics of migration are meticulously exploited by rival politicians and political parties, policy actors, and other stakeholders to frame the issue, orient policy and mobilize support or acquiescence to their cause (usually securitization versus accommodation). The stakes and policy implications are huge as a determination of a migrant as an "illegal migrant", a "refugee" or an "asylee" imposes different sets of obligations and policies on the recipient state.

This paper probes into the discourse on migration with a focus on its framing by pro and antimigration actors and stakeholders and how this has affected policy decisions and actions concerning the issue. It takes a case-study of Western democracies (Europe and the United States) where a clear dichotomy has emerged among populists and nationalists, on the one hand and globalists, and liberal institutionalists on the other on how to approach the migration challenge. It examines the securitization of migration by populist movements and politicians and the pros and cons of an open border policy. It proposes policy recommendations on a comprehensive solution to issues of migration.

\section{Framing the migration Debate in Europe and the US}

The years 2015 and 2016 witnessed a phenomenal challenge in the debates over migration across the Atlantic. On the one hand, Europe was faced with a migrant influx as more than a million migrants arrived its shores through the Mediterranean Sea (deHahn 2019). The crisis was compounded by the fact that the Mediterranean crossing took away the lives of 3,771 individuals in 2015 and an appalling 
total of 5,096 lives in 2016 (UNHCR 2018). This crisis of unprecedented proportion easily drew a wedge between European Leaders. While Angela Merkel's Germany opted for an "Open Door" policy, stretching its arms to welcome more than a million Syrian, Afghan and Iraqi refugees (De La Baume 2017); Viktor Orbán's Hungary went the opposite direction by building a 13-foot tall, 325-mile-long border wall along its borders with Serbia and Croatia (S4Cnews 2018).

The political discourse of migration was framed differently among politicians, parties and countries that supported an open-door approach and those that preferred a hardline approach. From an ideological stand point, the dichotomy on the framing of migration pitted globalist and liberal institutionalists on the one hand and nationalists and populist on the other. Globalists and liberal institutionalists generally tend to be more receptive to international migration. Migration in the perspective of globalists is the engine of globalization. As Daly (2004) puts it, globalization represents "the effective erasure of national boundaries-opening the way not only to free mobility of capital and goods but also, in effect, to free movement (or uncontrolled migration) of vast labor pools from regions of rapid population growth".

The language or diction used in the framing the migration discourse in migrant friendly countries in Europe at the wake of the migrant crisis was focused on giving it's a positive connotation or spin. Two countries where the aforementioned rhetoric was dominant were Germany and Sweden. A report commissioned by the United Nations High Commissioner for Human Rights (Berry et al. 2016) found out that during the European migrant crisis in countries like Germany and Sweden that opted for an open door approach used overwhelmingly used the migrant friendly terms 'refugee' and 'asylum' by $91 \%$ and $75.3 \%$ respectively for both. In Greece, which took in over 271,000 migrants in 2015 (MPC 2019), Siapera (2019) points out the important role grassroots refugee support group played in framing the discourse in favor of assisting refugees during the migrant crisis.

The overwhelming majority of European Union states however opted for a hardline approach on migration. Most of them like Hungary and its Visegrád neighbors, and Italy, witnessed the rise of nationalist and populist governments prone to the securitization of migration. The public and political discourses, media framing and public opinion in most of these countries tend to reify the security threat posed by migrants and push an antagonistic or derogatory label and perception of migration and migrant.

In the Netherlands, for instance, Brouwer et al (2017) introduce the concept of 'crimmigration' (the criminalization of migration). They point of that "the adoption of restrictive migrant policies and the strong anti-migration discourse surrounding these policies".

Chebel d'Appollonia (2015) on her part traces the securitization of migration (immigrationsecurity nexus) in France to a decade long process which originated from a conviction in the 1980s that the presence of immigrants created a socio-economic menace to French natives. This was brought to the fore by the National Front which made is part of its political propaganda. This issue was reinforced by the terrorist attack against Charlie Hebdo (a French satirical magazine) in 2015 which also contributed to shape public opinion against migrants in France.

The strongest anti-migration rhetoric in Europe has undoubtedly been that of Hungarian Prime Minister Viktor Orbán. His vitriolic attack at the EU and persistent anti-immigration rhetoric is second to none. In 2016, the Hungarian government under Orbán launched an anti-immigration campaign with billboards targeting EU Commission President Jean-CLaude Junker and Hungarian US Based billionaire George Soros of a plot to destroy Europe's civilization by opening up to masses of Moslems (Dunai 2019). Bocskor (2018) also highlights the anti-immigration discourse that underpinning the national consultation campaign on the issues of "immigration and terrorism held by the Hungarian government in 2015 . He points out: "The consultation framed immigration as both an economic and security threat and conflated asylum seekers, economic migrants and terrorists, as well as regular and irregular migration" (Ibid., p.551).

The dichotomy in the framing of migration between pro and anti-immigration camps is more glaring in the US, which has witnessed an unprecedented upsurge in political polarization in recent times. The anti-immigration camp championed by President Donald Trump has essentially focused 
its framing on the securitization of migration. Trump made the building of a wall across the US Southern borders, the signature promise of his 2016 presidential campaign and so far has coined his rhetoric around it. From the "Build the Wall"; "Finish the Wall" placards in his campaign rallies across the US; his Oval Office Address on the Border Wall; and the "National Emergency" declaration, Trump has been consistent in framing migration as a national security issue. Gessen (2018) notes Trump's use of phrases like "criminal aliens"; "very bad people"; "national emergency" and "safety of every single American" to pass across his message.

The migration discourse is also dominated by the "them-versus-us" framing under which "restrictionist groups" place US political leaders on the spot by insisting they let the public know the side they are on (that of pro-immigrant groups or that of those standing against "open borders", "immigrant terrorists" and "mass immigration" (Barry 2007).

On the framing of migration from the pro-immigration camp, Shepard (2016) notes the phenomenon among a growing number of American cities to frame themselves as "immigrantfriendly" cities. She points out that such designation is used as a strategy for urban regeneration and the promotion of economic revival.

In a study on frames utilized in the news coverage of immigration debate in the US during election years (from four major U.S. newspapers: New York Times; Los Angeles Times; St. Louis Post-Dispatch; and St. Petersburg Times), Kim and Wanta (2018) note that there is more likelihood for the human interest frame to possess a pro-immigration tone in comparison to other frames.

Both sides of the migration debate in the US are impacted by the use of labels. In a study on the effect of labels on people's attitude towards immigrants, Ommundsen et al (2014) underscore that the terms; "unauthorized immigrants", "illegal immigrants", "illegal aliens", and "undocumented immigrants" bear different meanings though used interchangeably. Their research found out the use of "illegal immigrants" resulted to a lower positive attitude in comparison to the use of "undocumented immigrants".

\section{Policy Recommendation for a Comprehensive Solution on Migration}

The issue of migration presents both a daunting task and formidable opportunity for developing and developed states in today's world. In this era of globalization, perhaps the first step in tackling migration is to depoliticize its usage. Migration should cease to be used as a political tool by rival political camps to win support in times of elections without any concrete platform or sincere commitment to solve the problem. The European Union has made great strides in coming out with institutional solutions towards the migrant crisis is faced such as relocation and resettlement patrol of their common frontiers. However, in the US it is imperative for the legislative and the executive to work out a comprehensive solution towards the problem of migration.

To achieve a comprehensive solution, one of the pre-requisite would be the setting up of a committee of experts (custom and border patrol chiefs, immigration experts, civil society actors and other key stakeholders) to come out with a draft proposal on how to tackle the challenge of immigration. Such a proposal can form a working document for both the legislative and executive branch to draw inspiration and negotiate a solution.

Thirdly, best practices across the globe could also serve as an example. Cases like Sweden with its successful migrant integration program, and the European Union with its successful handling of the migrant crisis could also be helpful to the United States.

Lastly, multilateral efforts like the Global Compact on Migration should not be neglected. The documents contain important guidelines that can inspire a customized solution at the domestic level. Being an internationally negotiated agreement with non-binding recommendations, the Global Compact on Migration certainly benefits from a large endorsement and huge opportunities for international cooperation.

\section{Conclusion}

From the forgone analysis, it is evident that migration remains a very polarizing issue around the globe. Countries and their citizens, political leaders and their parties, differ significantly on how to confront the 
challenge of migration. While some advocate an 'open-door' policy others uphold a hardline approach focus towards border security. Globalization and securitization seems to be the catalyst behind these rival positions. The dichotomy on what approach to use is clearly manifested in the way the issue of migration is framed. This paper has examined the framing of migration in Europe and the US among pro and anti-immigration camps. It ends up with some recommendation on how the challenge of migration can be resolved and why not transformed into an opportunity to enhance corporation, economic growth and solidarity across the globe.

\section{References}

Barry, Tom. 2007. "Anti-Immigrant Backlash on the "Home Front." NACLA. Accessed May 62019. https://nacla.org/article/anti-immigrant-backlash-home-front.

Berry, Mike., Inaki Garcia-Blanco, and Kerry Moore. 2016. "Press coverage of the refugee and migrant crisis in the EU: A content analysis of five European countries." Geneva: United Nations High Commissioner for Refugees. Accessed May 6 2019. http://www.unhcr.org/56bb369c9.html.

Bocskor, Ákos. 2018. "Anti-immigration discourses in Hungary during the 'Crisis' year: The Orbán government's 'National Consultation' campaign of 2015.” Sociology 52(3): 551-568.

Brouwer, Jelmer, Maartje van der Woude, and Joanne van der Leun. 2017. "Framing migration and the process of crimmigration: A systematic analysis of the media representation of unauthorized immigrants in the Netherlands." European Journal of Criminology 14(1): 100-119.

Chebel d'Appollonia, Ariane. 2015. "Security, Identity, Adversity: The "French Touch" on the Securitization of Immigration". Accessed 6 May 2019. http://critcom.councilforeuropeanstudies.org/security-identity-adversitythe-french-touch-on-the-securitization-of-immigration/.

Daly, Herman E. 2004. "Population, Migration, and Globalization." World Watch Magazine, September/October 2004, 17(5). http://www.worldwatch.org/node/559 Daly, H. 2004. Population,Migration, and Globalization

deHahn, Patrick. 2019. "The EU claims the migrant crisis is over in Europe-that doesn't mean it's over." Accessed 6 May 2019. https://qz.com/1570617/refugees-in-africa-struggle-to-reach-europe-as-the-eu-says-migrant-crisis-isover/.

de La Baume, Maïa. 2017. “Angela Merkel defends open border migration policy.” POLITICO. Accessed 30 April 2019. https://www.politico.eu/article/angela-merkel-defends-open-border-migration-refugee-policy-germany/.

Dunai, Marton. 2019. "Hungary defies demands for apology over anti-EU rhetoric." REUTERS. Accessed 6 May 2019. https://www.reuters.com/article/us-hungary-eu-epp-fidesz/hungary-defies-demands-for-apology-over-anti-eurhetoric-idUSKCN1QN103.

Gessen, Masha. 2018. "How the Media Normalizes Trump's Anti-Immigrant Rhetoric.” The New Yorker. Accessed 6 May 2019. https://www.newyorker.com/news/our-columnists/how-the-mainstream-media-normalizes-trumpsanti-immigrant-rhetoric.

Kim, Jeesun, and Wayne Wanta. 2018. "News framing of the US immigration debate during election years: Focus on generic frames." The Communication Review 21(2): 89-115.

MPC. 2019. "Greece - Migration Policy Centre." Migration Policy Centre. Accessed 6 May 2019. http://www.migrationpolicycentre.eu/greece/.

Ommundsen, Reidar, Knud S. Larsen, Kees van der Veer, and Dag-Erik Eilertsen. 2014. "Framing unauthorized immigrants: The effects of labels on evaluations." Psychological reports 114(2): 461-478.

Siapera, Eugenia. 2019. "Refugee Solidarity In Europe: Shifting The Discourse". European Journal Of Cultural Studies 22 (2): 245-266. doi:10.1177/1367549418823068.

S4Cnews. 2018. "Fact check: Did Hungary reduce illegal migration by $99 \%$ with a border wall?" Stand for Christians. Accessed 6 May 2019. https://en.s4c.news/2018/11/02/_trashed-3/.

Shepard, Erika A. 2016. "The Emerging "Immigrant-Friendly" City: How and why cities frame themselves as welcoming places to immigrants.” ScholarWorks@ UVM. Accessed $6 \quad$ May 2019. https://scholarworks.uvm.edu/cgi/viewcontent.cgi?article=1028\&context=castheses. 